\title{
Assessing the Level of Heavy Metals Concentration in Soil around Transformer at Akoko Community of Ondo State, Nigeria
}

\author{
${ }^{* 1}$ OGUNLANA, R; ${ }^{2}$ KORODE, AI; ${ }^{3}$ AJIBADE, ZF \\ ${ }^{*}$ Department of Physics, Faculty of Science, Adekunle Ajasin University, Ondo State, Nigeria \\ ${ }^{2,3}$ Department of Petroleum Engineering and Geosciences, Petroleum Training Institute, Effurun, Nigeria
}

*Corresponding Author Email: rotimiogunlana@gmail.com

\begin{abstract}
Some heavy metals have bio-importance as trace elements but the bio-toxic effects of many of them in human biochemistry are of great concern. The level of heavy metals concentrations of transformer oil polluted soil was assessed in Akungba Akoko community of Ondo State, Nigeria using Atomic Absorption Spectrophotometer. The concentration of heavy metals investigated ranges from: Cu (1400-18)mg/kg, Fe (96700- 15500)mg/kg, Cd (2$0.5) \mathrm{mg} / \mathrm{kg}, \mathrm{Mn}(62-29) \mathrm{kg} / \mathrm{mg}, \mathrm{Ni}(5-1) \mathrm{mg} / \mathrm{kg}, \mathrm{Al}(27-11) \mathrm{mg} / \mathrm{kg}, \mathrm{Zn}(1400-44) \mathrm{mg} / \mathrm{kg}, \mathrm{Pd}(68-20) \mathrm{mg} / \mathrm{kg}$ and Ca (570$135) \mathrm{mg} / \mathrm{kg}$. From the study, it was observed that some transformer sites had more concentration of heavy metals than others, as a result of the heavy metals content of the transformer soil released to the surrounding soil, while in some samples of these heavy metals were absent or are below detection limit. Comparing the results with the World Health Organisation (W.H.O) maximum allowable limit in soil with results of the results of different samples collected. majority of the results were found to fall below W.H.O limit which implies that those sites are still contamination free with respect to the specific heavy metal and caution needs to be taken urgently to avoid potential contamination. Meanwhile, heavy metal concentration at some sites have gone beyond the W.H.O maximum allowable limit, calling for immediate remediation of the site.
\end{abstract}

DOI: $\underline{\text { https://dx.doi.org/10.4314/jasem.v24i12.26 }}$

Copyright: Copyright (C) 2020 Ogunlana et al. This is an open access article distributed under the Creative Commons Attribution License (CCL), which permits unrestricted use, distribution, and reproduction in any medium, provided the original work is properly cited.

Dates: Received: 03 October 2020; Revised: 20 November 2020; Accepted: 11 December 2020

Keywords: Heavy metals, concentration, transformer oil, contamination

Precambrian Basement Complex Rock is the underlined Geology formation of Akungba Akoko, a part of Akoko Southwest of Ondo State, Nigeria. Electricity transformers are sited in major parts of the Studied Area. This has led to heavy metals contamination through transformer oil in contact with the surrounding soil, which could be of high risk to human health. Consequently, there is need to assess the level of these heavy metals concentration in the soil around the transformer in the studied area, so as to ascertain the safety of the public to the effect of these heavy metals. (Opeyemi et al., 2017). This study is carried out to assess soil pollution level around transformers in Akungba Akoko by heavy metals in other to so as to investigate the safety of the inhabitants to the effect of these heavy metals. Heavy metals is the terminology used for any metallic chemical elements with a comparatively high density which might be vicious or harmful despite low quantity of it in soils. It can be ingested gradually into the body through water, food and air which has the tendency of accumulating over a long period. (Lenntech 2004). They can have detrimental effect in human body by bio-amassing in living things through different ways. They are transferred and fragmented into tissue binding body cells to protein in human body, thereby instigating the destruction of major molecular organ and interruption of their cellular function through nucleic acids. Consequently, heavy metals can have various pernicious effects in human body. This can result to mental disorder by affecting the central nervous system, destroy the blood constituent thereby affecting the kidneys, liver, lungs and other important delicate organ of the body which might be responsible for various disease situation. (Godwill et al, 2019). They are fundamentally derived from their ores through mineral processing technology. (Yahaya 2009, Peplow, 1999; Lenntech, 2004; UNEP/GPA, 2004; USDOL, 2004).Heavy metals concentration in soil samples can be measured using nuclear and AAS (Atomic Absorption Spectrometry), ICP-MS (Inductively Coupled Plasma Mass Spectrometry). For the purpose of this study, Atomic Absorption Spectrometry AAS was used to evaluate the presence of heavy metals in the soil sample. Transformer oil is an oil that has outstanding electrical insulating properties, which is stable at high temperature. It is used in some types of high voltage capacitor, some

*Corresponding Author Email: rotimiogunlana@gmail.com 
types of high voltage switches, fluorescent lamp ballast, oil-field transformers and circuit breakers. A transformer oil can serve as Coolant as well as to insulate, suppress corona discharge and arcing. (Gill, 2009) Polychlorinated biphenyls (PCBs) are a group of tasteless and odourlesss artificial chemicals, which are oily solid or liquid and nearly yellow in colour. PCBs are mostly used in capacitors and transformers and are very stable mixtures that are resistant to extreme temperature and pressure. More so, they are very useful in making Plasticizers, Lubricant, Heat transfer fluids and Hydraulic fluids. (Bruce Rauner, 2009). Transformer Oils are made up of metals such as copper, iron, lead, aluminum, silver and tin. Nowadays, PCBs often get to the environment due to transformer oil leakage, as a result of transformer failure, improper waste disposal, poor handling of damaged electrical equipment and spillage during oil change. Heavy metals are usually found in transformer oil due to their availability in the component of the transformer. Tin, Zinc and Silver are found in some superficial components, Copper in transformer windings, Lead in soldered connectors and joints, Iron in the transformer tank and core and Aluminum in ceramic insulators and coils. Leakages from the devices like transformers are collected using Oil Pits which are usually found below the transformer. An oil collecting pit is made up of an outlet and the like, a sink funnel (tank), a grate and an oil tank. Specific Regulations are often followed during its construction, which states that an oil pit is not allowed to have a bottom, and that oil can be permitted to sink into the ground. This is the major reason behind environmental pollution and soil contamination with heavy metals and PCBs. (Stojic et al., 2014).

\section{MATERIALS AND METHODS}

Description of Location Sites: Several transformers location in Akungba Akoko, Ondo State were used as case study for this research work. The list of transformers visited is shown in table 1 AkungbaAkoko lies between coordinates $7^{\circ} 28^{\prime} 0^{\prime \prime}$ North and $5^{\circ}$ $44^{\prime} 0$ " East. It is a small town located in Akoko-land in Ondo State, Nigeria. (Figure 1)

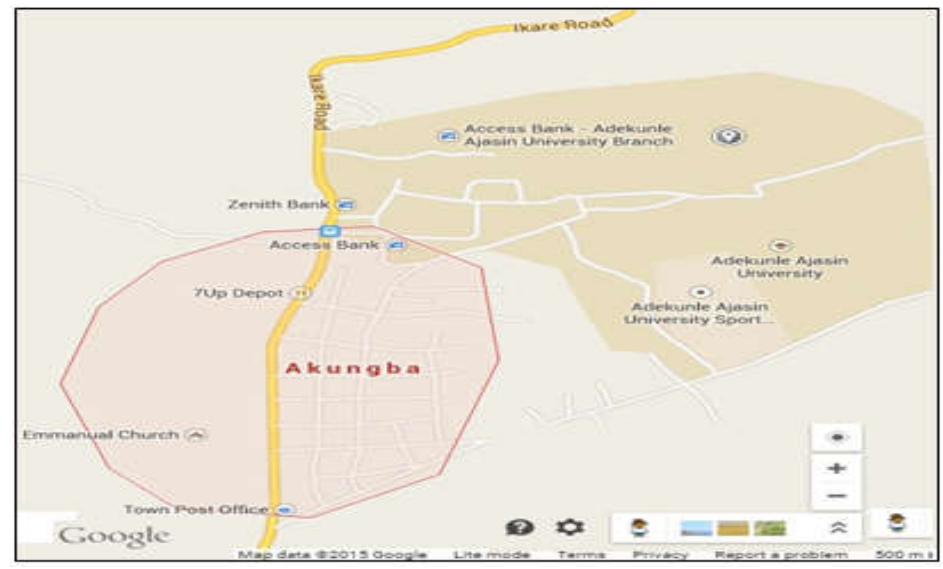

Fig 1 Location Map Of Akungba Akoko

Table 1. Descriptions of Location Sites

\begin{tabular}{|c|c|c|c|c|c|c|}
\hline$\overline{\mathbf{S} / \mathbf{N}}$ & Sample Site & Sample Code & Site Coordinate & Time & Drainage & Elevation \\
\hline$\overline{1 .}$ & Holy Trinity & HT & $7.473467^{0} \mathrm{~N}, 5.736037^{0} \mathrm{E}$ & 11:16AM & Yes & $15 \mathrm{Ft}$ ASL \\
\hline 2. & Blue House Junction & $\mathrm{BH}$ & $7.475298^{0} \mathrm{~N}, 5.736088^{0} \mathrm{E}$ & 11:32AM & Yes & $17 \mathrm{Ft} \mathrm{ASL}$ \\
\hline 3. & Supere Junction & SJ & $7.449437^{0} \mathrm{~N}, 5.792333^{0} \mathrm{E}$ & 10:07AM & Yes & $10 \mathrm{Ft} \mathrm{ASL}$ \\
\hline 4. & Iwaro Junctuion & $\mathrm{IJ}$ & $7.462040^{\circ} \mathrm{N}, 5.733364^{0} \mathrm{E}$ & $1: 29 \mathrm{PM}$ & Yes & $17 \mathrm{Ft} \mathrm{ASL}$ \\
\hline 5. & Ohiz Villa & $\mathrm{OV}$ & $7.445670^{\circ} \mathrm{N}, 5.7332214^{0} \mathrm{E}$ & $10: 31 \mathrm{AM}$ & Yes & 9Ft ASL \\
\hline 6. & Supere Police Station & SP & $7.438701^{0} \mathrm{~N}, 5.764218^{0} \mathrm{E}$ & 10:57AM & Yes & 8Ft ASL \\
\hline 7. & Premier Perier & $\mathrm{PP}$ & $7.464696^{0} \mathrm{~N}, 5.735309^{0} \mathrm{E}$ & $10: 20 \mathrm{AM}$ & No & $10 \mathrm{Ft}$ ASL \\
\hline 8. & Mfm Junction & MJ & $7.479044^{0} \mathrm{~N}, 5.737534^{0} \mathrm{E}$ & $12: 05 \mathrm{PM}$ & Yes & $12 \mathrm{Ft} \mathrm{ASL}$ \\
\hline 9. & University Station & US & $7.476179^{0} \mathrm{~N}, 5.731439^{0} \mathrm{E}$ & $12: 32 \mathrm{PM}$ & No & 9Ft ASL \\
\hline 10. & Control Sample & $\mathrm{CS}$ & $7.486170^{\circ} \mathrm{N}, 5.731438^{0} \mathrm{E}$ & & No & $12 \mathrm{Ft} \mathrm{ASL}$ \\
\hline
\end{tabular}

Sample Collection: The following materials were used for sample collections; Hand Gloves, Plastic Container, Collecting Spoon, Polythene Bag and GPS. Soil samples around ten transformers were selected in the study area (Akungba Akoko). The soil samples were taken within two days during the dry season period. (Yahaya et al., 2009) confirmed that the concentration of heavy metal in soil is higher in dry season than in 
rainy season because more heavy metals are lost in the soil due to run-off and infiltration in rainy season which are absent in dry season. The geographical coordinates of each transformer was also taken and recorded using a GPS device. The collected samples were then transported to the Federal University of Technology Akure Ondo State for the elemental analyses of heavy metals.

Elemental Analyses: The apparatus used for the elemental analyses are; Weighing balance, Digestion block(Q- BLOCK), Digestion tube (50mls), Pipette, Beaker and AAS Buck Scientific Device while the Reagents used are; Nitric Acid and Hydrochloric Acid.

Sample Preparation: The soil samples were pre dried. $0.5 \mathrm{~g}$ of samples were weighed using analytical balance into a digesting tubes and $10 \mathrm{ml}$ aqua-regia solution were added and heated in a digestor at $7000 \mathrm{C}$ until the fume of nitric acid and a clear solution obtained. The resulting solution were filtered and the filtrate made up with distilled water into a $50 \mathrm{ml}$ standard volumetric flask. The digests were analyzed for metals using Atomic Absorption Spectrometer manufactured by buck scientific, model VGP21.

Sequential Extraction of Heavy Metals from Soil Sieving: Sieving of soil samples were performed by an atomic testing sieve shaker with the following size fractions: $>1000,>495,>350,>150$, and $>75 \mu \mathrm{m}$.

Acid Digestion: Homogenous and grounded bulk soil samples $(0.1 \mathrm{~g})$ are treated with $4 \mathrm{ml}$ of an oxidizing mixture (HNO3: $\mathrm{HCI}=3: 1$ ) and $6 \mathrm{ml} \mathrm{HF}$ in a Teflon recipient put in a microwave oven $(800 \mathrm{w}, 4 \mathrm{~min} ; 400$ w, $4 \mathrm{~min}, 800 \mathrm{w}, 4 \mathrm{~min}$; $20 \mathrm{~min}$. of ventilation). Recovered sample are then treated with $5.6 \mathrm{~g} \mathrm{HNO}_{3}$ to avoid silica evaporation and diluted to $100 \mathrm{ml}$ by deionized water. Metal concentrations in solution were determined by atomic Absorption Spectrometer (AAS, Perkin Elmer Model 306).

Step 1: $5 \mathrm{~g}$ of soil sample was treated with $45 \mathrm{ml}$ of ammonium acetate IM at $\mathrm{pH} 5$ with acetic acid under stirring for 24 hours at room temperature; suspension was then centrifuged at $300 \mathrm{rpm}$ for $20 \mathrm{~min}$, diluted to $100 \mathrm{ml}$ with deionised water and analysed by AAS. Step 11: The residual solid of the previous step was treated with $22.5 \mathrm{ml}$ of hydroxyl ammonium acetate following by acetic acid (25\%). After $24 \mathrm{~h}$ stirring at room temperature solid -liquid separation is performed by centrifugation as before and the metal bearing solution is diluted (to $100 \mathrm{ml}$ ) and analysed by AAS. Step 111: The residual solid of the previous step was treated with $12.5 \mathrm{ml}$ of $\mathrm{HCI}(0.1 \mathrm{~m})$ and stirred for 24 hrs at room temperature. As in previous steps, solid liquid separation was performed and the solution diluted to $25 \mathrm{ml}$ was analysed for metal concentrations. Step IV: The residual solid of the previous step was treated with $12.5 \mathrm{ml}$ of $\mathrm{NaOH}(0.5 \mathrm{~m})$ under stirring for $24 \mathrm{hrs}$ at room temperature for soil samples with large organic content; this treatment was repeated until a clear solution was obtained. All the solutions separated from the solid were then dried by an IR lamp at $60^{\circ} \mathrm{c}$ and then digested by using $4 \mathrm{ml}$ of $\mathrm{HNO}^{3} 65 \%$ and $2 \mathrm{ml} \mathrm{HF}(40 \%)$ in a microwave oven $(250 \mathrm{w}, 1$ $\mathrm{min}$; o w, $2 \mathrm{~min}$; $250 \mathrm{w}, 5 \mathrm{~min} ; 600 \mathrm{w}, 5 \mathrm{~min})$. The acid solution was then diluted to $25 \mathrm{ml}$ and analysed for metals by AAS. Step V: The residual solid of the previous step was treated with $12.5 \mathrm{ml}$ of $\mathrm{HNO}_{3}(8 \mathrm{M})$ and digested for $2 \mathrm{~h}$ at $80^{\circ} \mathrm{C}$. The solution was then diluted to $25 \mathrm{ml}$ and analyzed by AAS for metal concentrations.

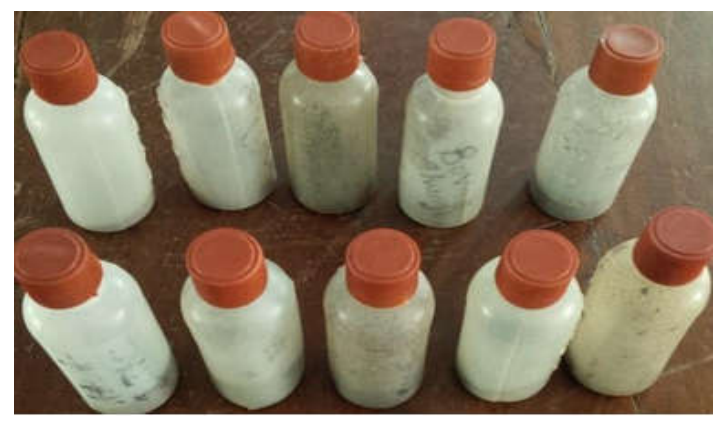

Fig 2: Cross Section of Soil Sample

\section{RESULT AND DISCUSSION}

Concentration of Heavy Metals in Soil Samples: The table 2 below shows the concentration of the heavy metals in the soil samples collected from selected sites. The concentrations of the heavy metals $(\mathrm{Cd}, \mathrm{Pb}, \mathrm{Mn}$, $\mathrm{Ca}, \mathrm{Al}, \mathrm{Fe}, \mathrm{Ni}, \mathrm{Cu}$, and $\mathrm{Zn}$ ) in the soil sample from the above transformer were determined, and the degree of heavy metal pollution in the soils was assessed. The ranges of concentration $(\mathrm{mg} / \mathrm{kg})$ of heavy metals in the 10 studied areas are as follows.

Copper (Cu): The concentration of copper in the soil sample has the highest in the sample BH $(1400 \mathrm{mg} / \mathrm{kg})$ and the lowest concentration in the sample HT $(18.00 \mathrm{mg} / \mathrm{kg})$, while no copper was detected in the control sample or its BDL (below determine level). Comparing the results with W.H.O maximum allowable limit for copper in the soil, only the sample collected at $\mathrm{BH}$ has value above the recommended level of $100 \mathrm{mg} / \mathrm{kg}$ while others are still within the limit. This implies that the concentration of copper in all other locations are still permissible. 
Table 2: Concentration of Heavy Metals in soil samples of areas considered

\begin{tabular}{|c|c|c|c|c|c|c|c|c|c|}
\hline $\begin{array}{l}\text { Soil } \\
\text { Sample }\end{array}$ & $\begin{array}{l}\mathrm{Cu} \\
(m g / k g)\end{array}$ & $\begin{array}{l}\mathrm{Fe} \\
m g / k g\end{array}$ & $\begin{array}{l}\mathrm{Cd} \\
m g / k g\end{array}$ & $\begin{array}{l}\mathrm{Mn} \\
m g / k g\end{array}$ & $\begin{array}{l}\mathrm{Ni} \\
m g / k g\end{array}$ & $\begin{array}{l}\mathrm{Al} \\
\mathrm{mg} / \mathrm{kg}\end{array}$ & $\begin{array}{l}\mathrm{Zn} \\
m g / k g\end{array}$ & $\begin{array}{l}\mathrm{Pd} \\
\mathrm{mg} / \mathrm{kg}\end{array}$ & $\begin{array}{l}\mathrm{Ca} \\
\mathrm{mg} / \mathrm{kg}\end{array}$ \\
\hline$\overline{\mathrm{BH}}$ & 1400.00 & 22880.00 & 1.00 & 62.00 & 5.00 & 27.00 & 1400.00 & 68.00 & 148.00 \\
\hline PP & 41.00 & 31600.00 & ND & 42.00 & 1.00 & 12.00 & 188.00 & 29.00 & 164.00 \\
\hline IJ & 71.00 & 96700.00 & ND & 54.00 & 2.00 & 24.00 & 640.00 & 38.00 & 448.00 \\
\hline SJ & 26.00 & 15500.00 & ND & 36.00 & 2.00 & 11.00 & 44.00 & 20.00 & 570.00 \\
\hline OV & 48.00 & 85000.00 & 2.00 & 33.00 & ND & 14.00 & 1020.00 & 55.00 & 135.00 \\
\hline HT & 18.00 & 61100.00 & ND & 29.00 & 1.0 & 14.00 & 46.00 & 49.00 & 169.00 \\
\hline SP & 43.00 & 93000.00 & ND & 37.00 & ND & 13.00 & 289.00 & 71.00 & 205.00 \\
\hline MJ & 26.00 & 67600.00 & ND & 47.00 & 3.00 & 17.00 & 112.00 & 44.00 & 278.00 \\
\hline US & 32.00 & 54600.00 & 0.50 & 36.00 & 2.00 & 15.00 & 715.00 & 67.00 & 197.00 \\
\hline $\mathrm{CS}$ & ND & 1000.00 & ND & 12.00 & ND & 9.00 & 130.00 & 11.00 & 61.00 \\
\hline
\end{tabular}

Table 3. Maximum allowable limit of heavy metals concentrations in soil ( $\mathrm{mg}^{\wedge} \mathrm{kg}^{\prime}$ ) by World Health Organisation (WHO). (Chioma et al., 2014) with their respective mean values and standard deviation.

\begin{tabular}{lllll}
\hline S/N & $\begin{array}{l}\text { Heavy } \\
\text { metals }\end{array}$ & $\mathbf{m g} / \mathbf{k g}$ & $\begin{array}{l}\text { Mean } \\
\text { value }\end{array}$ & $\begin{array}{l}\text { Standard } \\
\text { deviation }\end{array}$ \\
\hline $\mathbf{1 .}$ & $\mathrm{Cu}$ & 100 & 189.4444 & 454.2263 \\
$\mathbf{2 .}$ & $\mathrm{Fe}$ & 50000 & 58664.44 & 30202.8 \\
$\mathbf{3 .}$ & $\mathrm{Cd}$ & 3 & 0.388889 & 0.697217 \\
$\mathbf{4 .}$ & $\mathrm{Mn}$ & 2000 & 41.77778 & 10.69787 \\
$\mathbf{5 .}$ & $\mathrm{Ni}$ & 50 & 1.777778 & 1.563472 \\
$\mathbf{6 .}$ & $\mathrm{Al}$ & $\mathrm{N} . \mathrm{A}$ & 16.33333 & 5.522681 \\
$\mathbf{7 .}$ & $\mathrm{Zn}$ & 300 & 494.8889 & 481.203 \\
$\mathbf{8 .}$ & $\mathrm{Pd}$ & 100 & 49 & 18 \\
$\mathbf{9 .}$ & $\mathrm{Ca}$ & N.A & 257.1111 & 151.8029 \\
\hline \multicolumn{5}{c}{ N.A means note available } \\
\hline \multicolumn{4}{c}{}
\end{tabular}

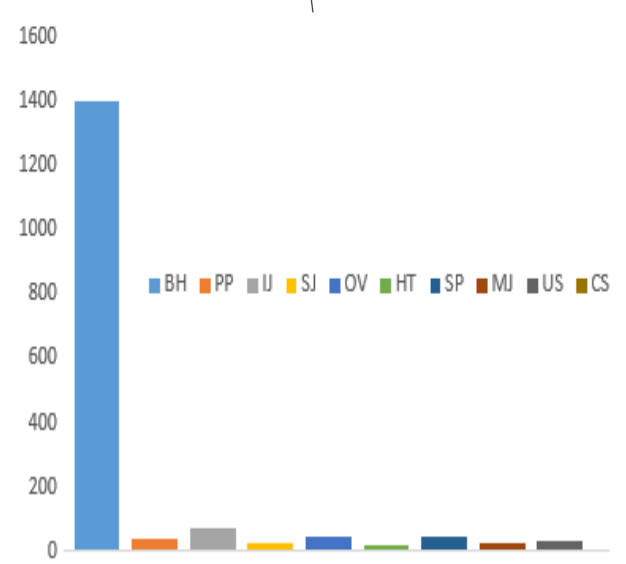

Fig 3 Graphical Representation of the concentration of Copper $\mathrm{Cu})$ in the tested samples

Iron $(\mathrm{Fe})$ : The concentration of iron in the soil sample has the highest in the sample IJ $(96700 \mathrm{mg} / \mathrm{kg})$ and the lowest concentration in the sample SJ $(15500 \mathrm{mg} / \mathrm{kg})$ while it is $1000 \mathrm{mg} / \mathrm{kg}$ at the control sample CS. The concentration of iron range from (96700.00-15500) $\mathrm{mg} / \mathrm{kg}$ comparing the results for iron with W.H.O maximum allowable limit for iron which is $50,000 \mathrm{mg} / \mathrm{kg}$. Sample IJ, OV, HT, SP, MJ and US are all above the limit while sample BH, PP and SJ are still within permissible limit. The value $1000 \mathrm{mg} / \mathrm{kg}$ obtained at the control sample shows that the transfer oil has no impact in the location.

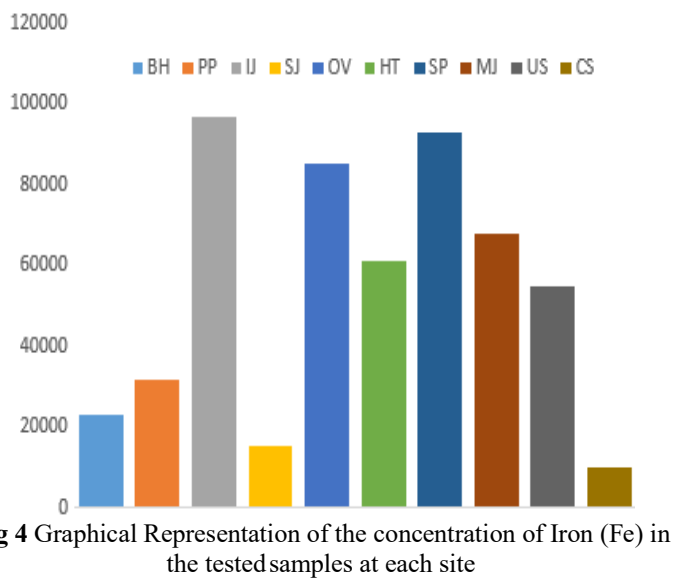

Cadmium (Cd): The concentration of cadmium in the soil sample has the highest in the sample $(2.00 \mathrm{mg} / \mathrm{kg})$ and the lowest concentration in the sample US $(0.50 \mathrm{mg} / \mathrm{kg})$, while no cadmium was detected sample PP, IJ, SJ, HT, ST and MJ as well as CS or it is below detected level BDL. The concentration of iron range from $(2.00-0.50) \mathrm{mg} / \mathrm{kg}$. Comparing the results for cadmium with W.H.O maximum allowable limit for cadmium, all samples collected are below the limit of $3 \mathrm{mg} / \mathrm{kg}$.

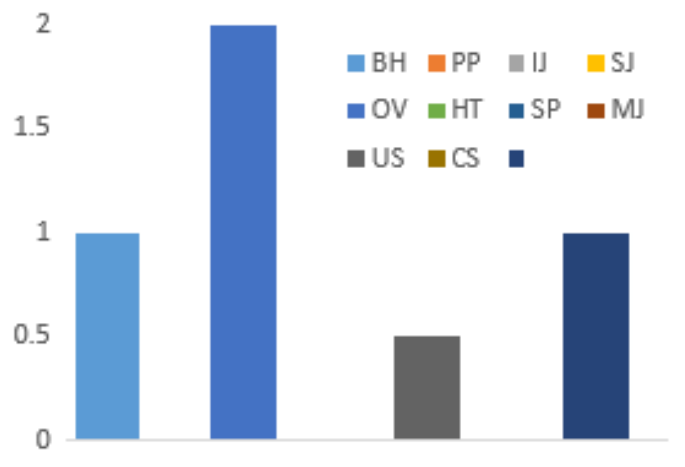

Fig 5: Graphical Representation of the concentration of Cadmium (Cd) in the tested samples at each site

Manganese (Mn): The concentration of manganese in the soil sample has the highest in the sample $\mathrm{BH}$ 
$(62.00 \mathrm{mg} / \mathrm{kg})$ and the lowest concentration in the sample HT $(29.00 \mathrm{mg} / \mathrm{kg})$, the concentration of manganese range from $(62.00-12.00) \mathrm{mg} / \mathrm{kg}$. Comparing the W.H.O maximum allowable limit for manganese which is $2000 \mathrm{mg} / \mathrm{kg}$ with the results of samples tested for manganese, it shows that all the samples are below the W.H.O limit as well as the control sample CS.

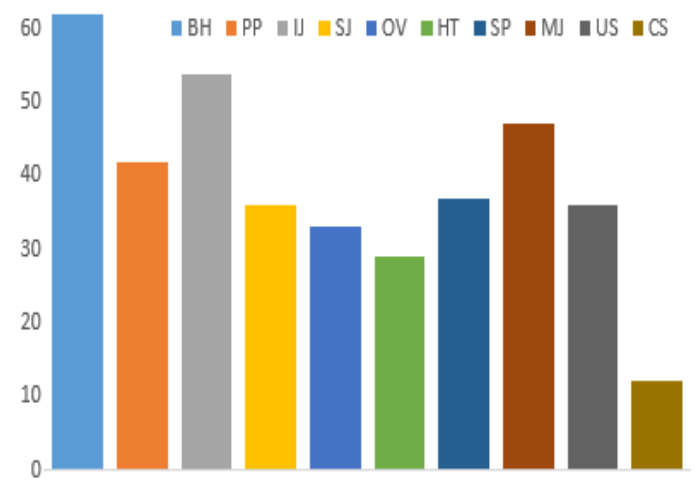

Fig 6: Graphical Representation of the concentration of Manganese $(\mathrm{Mn})$ in the tested samples at each site

Nickel (Ni): The concentration of nickel in the soil sample has the highest in the sample BH $(5.00 \mathrm{mg} / \mathrm{kg})$ and the lowest concentration in the sample HT and PP $(1.00 \mathrm{mg} / \mathrm{kg})$, while no nickel was detected in the sample OV, SP and CS or its BDL (below determine level). The concentration Nickel (Ni) range from (5.00-1.00) $\mathrm{mg} / \mathrm{kg}$. Comparing the result for Nickel with W.H.O maximum allowable limit for nickel, all samples collected are below the limit of $50 \mathrm{mg} / \mathrm{kg}$.

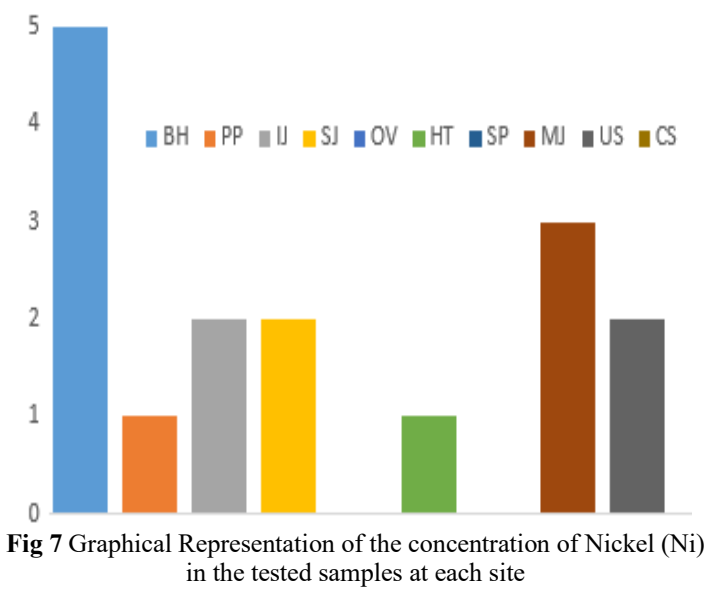

Aluminum (Al): The concentration of aluminum in the soil sample has the highest in the sample $\mathrm{BH}$ $(27.00 \mathrm{mg} / \mathrm{kg})$ and the lowest concentration in the sample SJ $(11.00 \mathrm{mg} / \mathrm{kg})$, the concentration of aluminum range from $(27.00-11.00) \mathrm{mg} / \mathrm{kg}$ while the control sample CS has a value of $9 \mathrm{mg} / \mathrm{kg}$. Comparing the result for aluminum with the W.H.O maximum allowable limit for heavy metals show that there is no guideline range for aluminum.

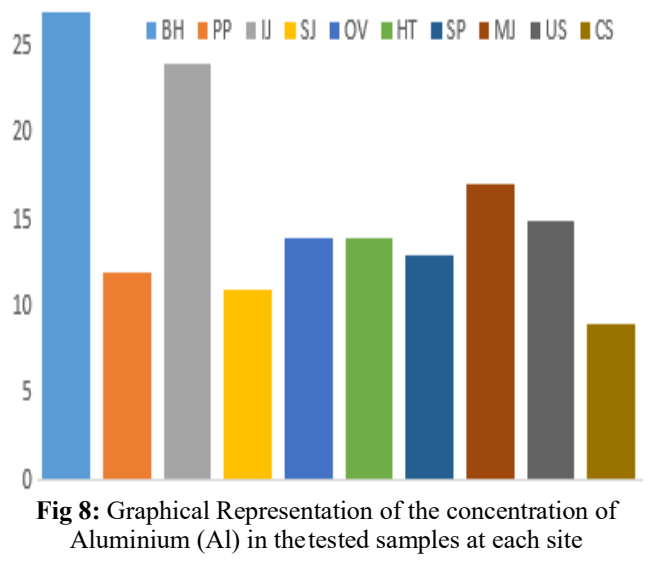

Zinc (Zn): The concentration of zinc in the soil sample has the highest in the sample BH $(1400 \mathrm{mg} / \mathrm{kg})$ and the lowest concentration in the sample HT $(44.00 \mathrm{mg} / \mathrm{kg})$, the concentration Zinc ( $\mathrm{Zn}$ ) range from (1400.00$44.00) \mathrm{mg} / \mathrm{kg}$. Comparing the results for zinc with W.H.O maximum allowable limit for zinc which is $300 \mathrm{mg} / \mathrm{kg}$, sample BH, IJ, OV and US are above the limit while sample PP, SJ, HT, SP, MJ and CS are below the limit.

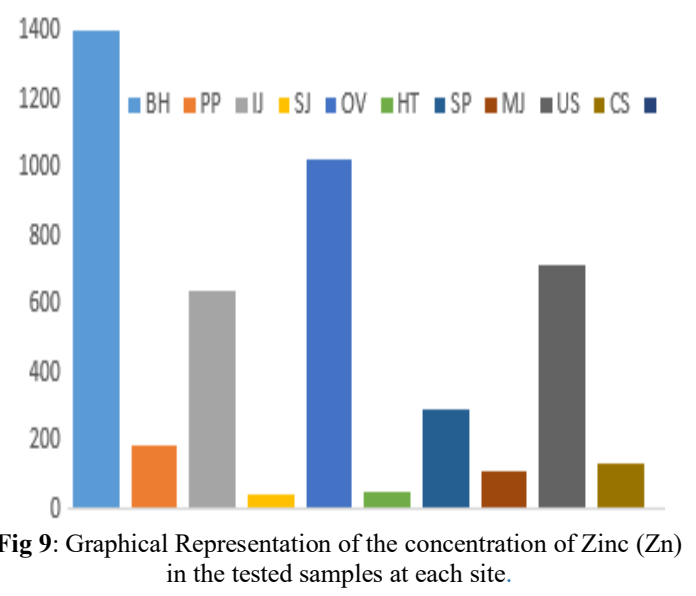

Lead $(P d)$ : The concentration of lead in the soil sample has the highest in the sample SP $(71 \mathrm{mg} / \mathrm{kg})$ and the lowest concentration in the sample SJ $(20.00 \mathrm{mg} / \mathrm{kg})$, the concentration lead $(\mathrm{Zn})$ range from (71.00-20.00) $\mathrm{mg} / \mathrm{kg}$. Comparing the results of lead $(\mathrm{Pd})$ with the maximum allowable limit for lead which is $100 \mathrm{mg} / \mathrm{kg}$. It shows that all samples are moderate level because they fall below the limit. 
Calcium ( $\mathrm{Ca}$ ): The concentration of calcium in the soil sample has the highest in the sample SJ $(570 \mathrm{mg} / \mathrm{kg})$ and the lowest concentration in the sample $\mathrm{OV}$ $(135.00 \mathrm{mg} / \mathrm{kg})$. The concentration of Calcium $(\mathrm{Ca})$ ranges from (570.00-135.00) $\mathrm{mg} / \mathrm{kg}$ while the control sample CS has a value of $61 \mathrm{mg} / \mathrm{kg}$. Comparing the results for calcium with the W.H.O maximum allowable limit for heavy metals shows that there is no guideline range for calcium.
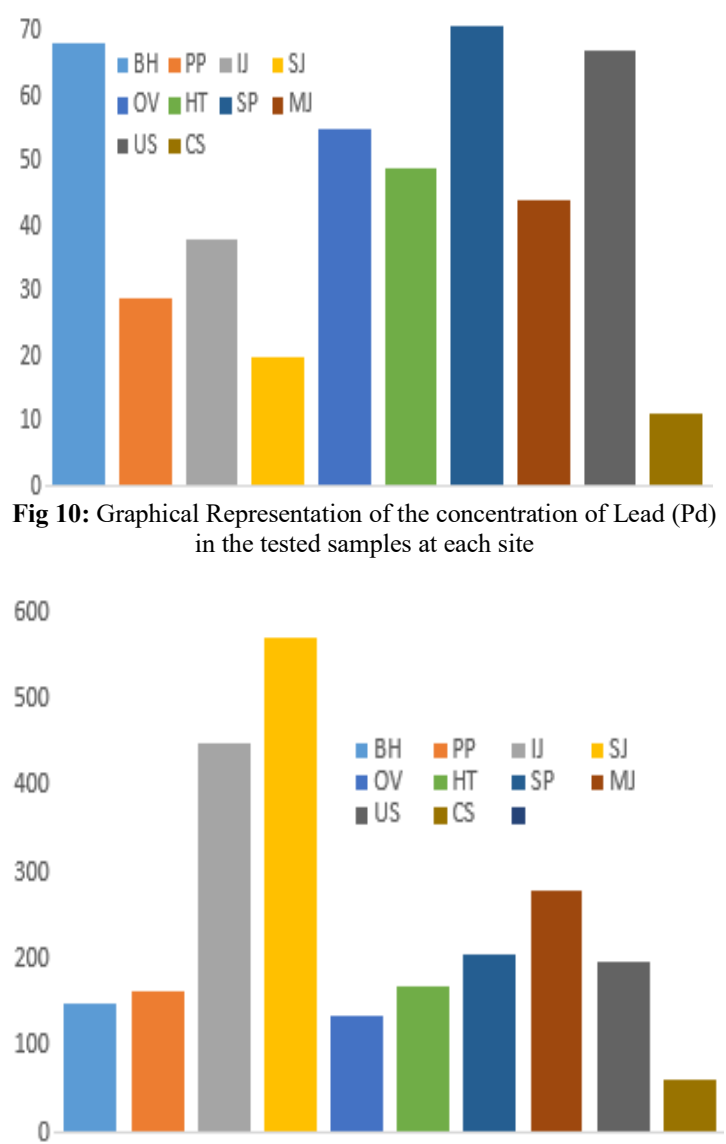

Fig 11: Graphical Representation of the concentration of Calcium (Ca) in the tested samples at each site

Table 3 above also reveals the mean and standard deviation of heavy metal concentration in the study location.

Statistical analysis showed that the average level (mean values) of heavy metal and the standard deviation of $\mathrm{Cd}(0.39 \mathrm{mg} / \mathrm{kg}, \quad 0.7 \mathrm{mg} / \mathrm{kg}), \quad \mathrm{Mn}$ $(41.8 \mathrm{mg} / \mathrm{mg}, 10.9 \mathrm{mg} / \mathrm{kg}), \mathrm{Ni}(1.78 \mathrm{mg} / \mathrm{kg}, 1.56 \mathrm{mg} / \mathrm{kg})$, $\mathrm{Al}(16.3 \mathrm{mg} / \mathrm{kg}, 5.52 \mathrm{mg} / \mathrm{kg}), \mathrm{Pb}(49 \mathrm{mg} / \mathrm{kg}, 18 \mathrm{mg} / \mathrm{kg})$ in comparism with their respective maximum allowable limit are still permissible. Meanwhile, Zn, $\mathrm{Cu}$ and $\mathrm{Fe}$ with mean and standard deviation value of $(494.889 \mathrm{mg} / \mathrm{kg}, \quad 481.2 \mathrm{mg} / \mathrm{kg}), \quad(189.44 \mathrm{mg} / \mathrm{kg}$, $454 \mathrm{mg} / \mathrm{kg})$ and $(58,664 \mathrm{mg} / \mathrm{kg}, \quad 30202.8 \mathrm{mg} / \mathrm{kg})$ respectively are above their W.H.O maximum allowable calling for their immediate remediation of the site (see table 3). This study investigates concentrations of heavy metals $(\mathrm{Cd}, \mathrm{Pb}, \mathrm{Mn}, \mathrm{Co}, \mathrm{Al}$, $\mathrm{Fe}, \mathrm{Ni}, \mathrm{Cu}$, and $\mathrm{Zn}$ ) in soil samples around transformers in Akungba Akoko. The results indicate that most of the areas where shown to have concentrations of this heavy metal $(\mathrm{Cd}, \mathrm{Pb}, \mathrm{Mn}, \mathrm{Ca}, \mathrm{Al}$, $\mathrm{Fe}, \mathrm{Ni}, \mathrm{Cu}$, and $\mathrm{Zn}$ ), though they could not be detected in some soil sample. It was observed that some soil samples have higher concentration of these metals than others, and this could be attributed to the presence of soil sample carrying heavier amount of these heavy metals. Other sites have low concentration of these heavy metals. This may be as a result of less contamination with those metals due to human activities. Concentration of these heavy metals could not be detected in some soil sample around transformer; the implication is that the concentration of these heavy metals is below detection limit or not present at all. These soil samples around the transformers have concentrations of heavy metals within the allowable limit; as a result may not appear to pose very serious environmental problems at the moment. However, this cause for some concern as continuous accumulation in the levels of heavy metals may occur with time and may result in health challenges.

Conclusion: The assessment of heavy metals contamination $(\mathrm{Cu}, \mathrm{Ca}, \mathrm{Zn}, \mathrm{Al}, \mathrm{Mn}, \mathrm{Ni}, \mathrm{Fe}, \mathrm{Pd}$ and $\mathrm{Cd})$ in the soils from selected transformer sites in Akungba Akoko was made in comparison with control site. The concentration of these metals in the soil is profiled according to W.H.O maximum allowable limit in soil for heavy metals and the results show that some of the soil are contaminated. The concentrations of these heavy metals at the transformer sites are higher than the values in the control site but majority of them were below the W.H.O maximum allowable limit for heavy metal in soil while the few that have gone beyond W.H.O recommendation demand immediate remediation of the site.

\section{REFERENCES}

Bruce, R; (2009). Polychlorinated biphenyls. Environmental health fact sheet, Illinious department of public health. http://www.idph.state.il.us/envhealth/factsheets/ polychlorinatedbiphenyls.htm

Chiroma, TM; Ebewele, RO; Hymore, K; (2014) Comparative assessment of heavy metal levels in soil, vegetables and urban grey waste water used 
for irrigation in Yola and Kano. Int. Ref. J. Eng. Sci., Vol. 3, $1-9$.

Gill, P; (2009). Electrical power equipment maintenance and testing (2nd ed.). Boca Raton: CRC Press. p. 193. ISBN 978-1-57444-656-2.

Godwill, AE; Paschaline, UF; Friday, NN; Marian, N; Unachukwu (2019). Mechanism and Health Effects of Heavy Metal Toxicity in Humans, Poisoning in the Modern World - New Tricks for an Old Dog?, Ozgur Karcioglu and Banu Arslan, IntechOpen, DOI: 10.5772/intechopen.82511. Available from: https://www.intechopen.com/books/poisoningin-the-modern-world-new-tricks-for-an-old-dog/mechanism-and-health-effects-of-heavy-metaltoxicity-in-human

Lenntech Water Treatment and Air Purification (2004). Water Treatment, Publish by Lenntech, Rotterdamseweg, Netherlands.

Opeyemi, H; Olowomofe, OM; Afolabi (2017). Elemental and Radioactivity levels in Soils around Transformers in Akungba-Akoko, Nigeria. Adekunle Ajasin University AkungbaAkoko, Ondo State, Nigeria. DOI: 10.5281/zenodo. 800630
Peplow, D (1999). Environmental Impacts of Mining in Eastern Washington, Centre for Water and Watershed Studies Fact Sheet, University of Washington. Seattle.

Stojic, N; Mira, P; Danica, M; Isidora, K (2014). Transformers as a potential for soil contamination. Metalurgija -Sisak then Zagreb-. 53. 689-692.

United Natios Environmental Protection/Global Program of Action (2004). Why the Marine Environment needs Protection from Heavy Metals. UNEP/GPA Coordination Office.

United State Department of Labour (2004). Occupational afety and Health Administration (OSHA); Safety and Health Topics: Heavy Metals. USDOL Publication, Washington, D.C.

Yahaya, MI. ohammad, S , Abdullahi, BK. (2009); Seasonal Variations of Heavy Metals Concentration in Abattoir Dumping Site Soil in Nigeria. J. Appl. Sci. Environ. Manage. Vol. 13(4) $9-13$ 